\title{
複数の波動が存在する振動場における 振動インテンシティに関する研究*
}

\author{
西, 島 基 史*1, 竹浩 史*2 \\ 三上真 人 $^{* 3}$, 小嶋 直 哉*4
}

\section{A Study on Vibration Intensity in Vibration Field with Multiple Waves}

\author{
Motofumi NISHIJIMA, Hirofumi TAKE, \\ Masato MIKAMI*5 and Naoya KOJIMA \\ ${ }^{* 5}$ Graduate School of Science and Engineering, Yamaguchi University, \\ 2-16-1 Tokiwadai, Ube-shi, Yamaguchi, 755-8611 Japan
}

\begin{abstract}
In order to utilize the vibration intensity (VI or structure intensity), it is necessary to clarify characteristics and usability of VI under conditions close to practical situations. The superposition of standing wave and traveling wave often occurs in actual structures. In the vibration field with a standing wave and a traveling wave, it has been reported that a curved energy flow is detected by VI unlike the case without the standing wave. It has not been validated whether the energy flow detected by VI in the case with standing wave is equal to the real energy flow. VI detects the transmission component of vibration energy. However, the standing wave is non transmission component. The influence of the standing wave on VI is still unclear. In this study, a thin plate model with a standing wave and a traveling wave was employed, and we investigated the influence of superposition of these waves on VI using finite element method (FEM) analysis. The usability of VI under this condition was evaluated. Main findings are as follows: The extra terms appear in the VI formula when the superposition of multiple waves occurs. The difference between VI with standing wave and that without it is generated by these terms. VI approximately detects real energy flows when amplitude ratio of traveling wave to standing wave is greater than five.
\end{abstract}

Key Words: Mehtod of Vibration Analysis, Vibration Intensity, Structure Intensity, Wave, Standing Wave, Traveling Wave, Curved Energy Flow, Finite Element Method

\section{1. 粕言}

現在，低振動や低騒音が製品に付加価值を与え，品質 の良否を決定する大きな因子となっており，振動低減を 考慮した設計開発の重要性が高まっている. 振動対策を 施す場合においては，効率的かつ効果的に対策を施すこ とが求められておう，予め振動場の情報を把握するため に, 振動源や振動伝搬経路の可視化が有効な手段となる. この具体的な手法の 1 つとして, 振動インテンシティ

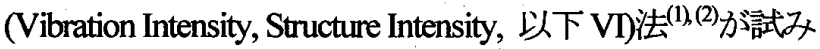
られている.

VI 法は振動エネルギーの流れをベクトルによって表 現する手法であり，これにより機械構造物表面の振動伝 搬現象を可視化することが可能となる．しかし，多くの

* 原稿受付 2010 年 6 月 24 日

*1 山口大学大学院理工学研究科(㞼 755-8611 宇部市常盤台 2$16-1)$.

*2 学生員, 山口大学大学院理工学研究科.

*3 正員, 山口大学大学院理工学研究科.

*4 正員, フェロー, 山口大学大学院理工学研究科.

E-mail : mmikami@yamaguchi-u.ac.jp
実構造物においては，端部や段差などの境界における反 射波の発生や，複数の振動源や振動流入経路の存在によ つて, 振動エネルギ一流れが複雑化している.このため, VI を実機へ適用した研究(3)へ(6)も存在するが，明確な振動 対策の指針を得られない場合もある，また，VI 法は振動 対策を施す上で指標となるため，実構造物に適用する前 に，上記のような振動が複雑に伝搬する振動場において も，振動エネルギ一流孔を正確に検出可能力検証する必 要がある. したがって，VI 法を効果的に活用するために は，実機の振動を想定した条件下において，本来の振動 エネルギー流れを検出可能な条件を抽出するなど，VIの 特性や有用性を明確にすることが必要であるといえる.

実機での振動において頻繁に見られる現象として，振 動の非伝搬成分である定在波成分と伝搬成分である進行 波成分の重ね合わせが挙げられる. 加振源より生じる進 行波と境界において生じる反射波の振幅が等しい場合に は完全な定在波が形成される. しかし，多くの場合には， 進行波と反射波の振幅は異なるため，定在波に加えて， その差が進行波として現れる. 定在波成分の存在する振 
動場においては，渦巻き状の流れなど，特徵的な流れが VIにより検出されることが示されている(7), (8). また，定 在波成分に進行波成分が別途付加された場合には, VIに より定在波成分を伴わない場合の流れとは異なる湾曲し た流れが検出されることが報告されている(9). しかし， 振動の非伝搬成分である定在波成分が，振動の伝搬成分 を捉えるVIに影響を及ぼす要因は,明らかになっておら ず，定在波成分を伴う場合に検出される流れが本来の工 ネルギー流れを捉えたものであるかも明確になっていな い.

そこで，本研究では，定在波成分である振動モ一 ドに進行波成分が別途付加された薄肉平板を対象と して，それらの波動の重称合わせが VI に及ぼす影 響を FEM による数值解析から調査した. 加えて, 同条件におけるVI の有用性について評価を行った。

\section{2. 解析方法}

$2 \cdot 1$ 屈曲波によるVIの算出方法 騒音一直接 的に変換されるのは面外方向の振動であるため, VI は一般に，薄板において屈曲波により伝搬される振 動エネルギ一流れを対象とする.本研究においても， 以降，屈曲波によるVIを対象とした議論を行う。

屈曲波による VI の定義式は，薄板の微小断面に 作用する単位幅当たりのせん断力, 曲げモーメント, ねじりモーメントにより，単位時間当たりになされ る仕事の和として定義される，VI の単位は W/m で ある．平面応力状態の仮定に基づき平板の曲げ理論 を適用すると，周波数領域における VI 算出式の $x$ 方向成分は，次式で表される。

$$
\begin{aligned}
V I_{x}(f)= & B\left\{F\left[\frac{\partial}{\partial x}\left(\nabla^{2} w\right)\right] \cdot F^{*}\left[\frac{\partial w}{\partial t}\right]\right. \\
& -F\left[\frac{\partial^{2} w}{\partial x^{2}}+v \frac{\partial^{2} w}{\partial y^{2}}\right] \cdot F^{*}\left[\frac{\partial^{2} w}{\partial x \partial t}\right] \\
& \left.-(1-v) F\left[\frac{\partial^{2} w}{\partial x \partial y}\right] \cdot F^{*}\left[\frac{\partial^{2} w}{\partial y \partial t}\right]\right\}
\end{aligned}
$$

ここで, $w$ は面外方向振動変位, $B$ は板の曲げ岡性, $\nabla^{2}$ は 2 次元ラプラシアン, $v$ はポアソン比, $f$ は周 波数, $F[$ ]はフーリエ変換値, * は共役複素数を示す. 式(1)の実数部を VI のアクティブ成分と呼び，アク ティブ成分の周波数領域における積分値は，エネル ギ一伝搬の時間平均值を表している. 式(1)を任意の 周波数帯域について積分することにより，周波数帯 域ごとの振動エネルギ一流れを検出することができ る. また, $y$ 方向成分の屈曲波 VI の算出式に関して も式(1)における $x$ と $y$ を置き換えることにより，同
様に表される。なお, ‘式(1)により VI を算出するた めに，12 箇所の差分点を配置する 12 点法 ${ }^{(10)}$ を用い た.

$2 \cdot 2$ 解析モデル 本研究では, 図 1 に示す正 方形薄肉平板の $3 \mathrm{~m} \times 3 \mathrm{~m}$ モデルを用いて FEM 解析 により検討を行った. FEM 解析には有限要素法構造 解析プログラム MSC.visual Nastran for Windows を用 いた.解析モデルの寸法は $x, y$ 方向ともに $3000 \mathrm{~mm}$, 板厚を $1.6 \mathrm{~mm}$ とし，周辺 4 辺の境界条件は単純支持 とした．正方形の中心を座標の原点とし，原点を加 振点とした。なお，VI を算出する解析領域は平板中 央の 1 辺 $1000 \mathrm{~mm}$ の正方形内部とした。 また，表 1 には解析モデルの物性值を示す.

$2 \cdot 3$ 加振条件 まず，固有周波数 $69.739 \mathrm{~Hz}$ の正弦波加振を入力し，定常状態の(9,9)モードを形 成させ，完全な定在波成分のみによる振動応答を得 た. (9,9)モードを形成するために入力した固有周波 数 $69.739 \mathrm{~Hz}$ の加振の振幅を $F_{s w}$ とし, $F_{s w}=1 \times 10^{-7} \sim$ $1 \times 10^{-2} \mathrm{~N}$ の範囲で変化させた.

また，静止状態の平板に振幅 $1 \mathrm{~N} の 69.739 \mathrm{~Hz}$ の正 弦波加振を入力し, 加振入力開始から 0.05 秒間分の $69.739 \mathrm{~Hz}$ の進行波成分のみによる振動応答を得た. なお，この 0.05 秒間においては，板端部で生じる反 射波が平板中央の 1 辺 $1 \mathrm{~m}$ の正方形解析領域内に到 達しないため，この進行波成分については，反射波 の影響が除外されている.

さらに，(9,9)モード形成時の定在波成分のみによ る応答と進行波成分のみによる応答を線形結合する ことで，同周波数の定在波成分に進行波成分が別途 付加された振動場を想定した。なお，定在波成分生 成用の加振に対し進行波成分付加用の加振は $\pi / 2$ の 位相遅れを有している.VI を算出する解析周波数は $69.739 \mathrm{~Hz}$ とした. 図 2 に進行波成分の変位の振幅 $A_{h w}$ と定在波成分の変位の振幅 $A_{s w}$ の加振点における 比 $\left(A_{t w} / A_{s w}\right)_{0}$ を定在波成分生成用の加振振幅 $F_{s w}$ に対 して示す．上述のとおり，進行波成分生成用の加振 振幅が $1 \mathrm{~N}$ であるのに対し，定在波成分生成用の加 振振幅は $F_{s w}=1 \times 10^{-7} \sim 1 \times 10^{-2} \mathrm{~N}$ の範囲で変化させて いる. $F_{s w}=1 \times 10^{-5}$ の場合には $\left(A_{n w} / A_{s w}\right)_{0}=1.35$ であり， それぞれの加振による応答は同程度である。 なお， $F_{s w}=1 \times 10^{-7}$ の場合には $\left(A_{w w} / A_{s w}\right)_{0}=135, F_{s w}=1 \times 10^{-2}$ の 場合には $\left(A_{m w} / A_{s w}\right)_{0}=0.00135$ である. 


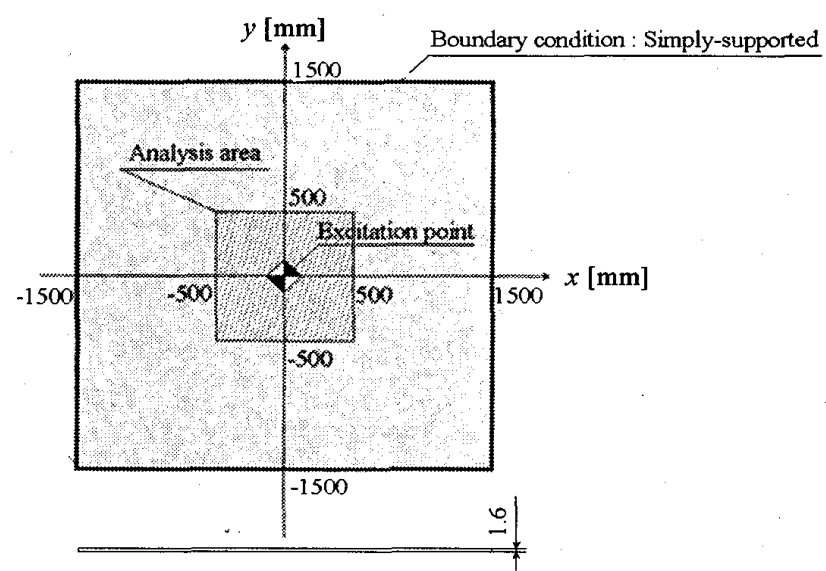

Fig. 1 FEM analysis model $(3 \mathrm{~m} \times 3 \mathrm{~m}$ thin plate $)$

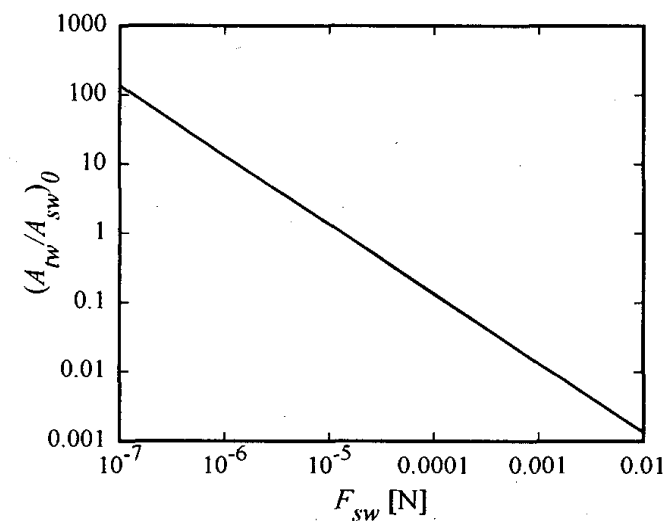

Fig. 2 Dependence of amplitude ratio at excitation point on amplitude of excitation force to form standing wave

Table 1 Material constants of the analysis model

\begin{tabular}{|c|c|}
\hline Young's modulus, $E[\mathrm{GPa}]$ & 206 \\
\hline Poisson's ratio, $v$ & 0.3 \\
\hline Mass density, $\rho\left[\mathrm{kg} / \mathrm{m}^{3}\right]$ & $7.86 \times 10^{3}$ \\
\hline
\end{tabular}

\section{3. 結果およひ考察}

\section{$3 \cdot 1$ 定在波成分と進行波成分を伴う場合の VI 分布}

まず，進行波成分のみによる VI を図 3 に示す.こ の進行波成分のみによる VI は, 解析領域全域にお いて加振源から放射状かつ直線的に分布している.

また，定在波成分を形成するための加振の振幅が $F_{s w}=1 \times 10^{-2} \mathrm{~N}$ の場合の(9,9)モードのみによるVIを図 4 に示す. 定在波成分は振動エネルギーを伝搬しな いため，いずれの $F_{s w}$ においてもエネルギ一伝搬を 捉える VI は解析領域全域で 0 となっている.
次に, $F_{s w}=1 \times 10^{-7}, 1 \times 10^{-5}, 1 \times 10^{-2} \mathrm{~N}$ の場合にお いて，定在波成分と進行波成分を伴う場合の VI を 図 5 に示す．定在波成分は非伝搬成分であるため， 定在波成分と進行波成分を伴う場合の VI は，進行 波成分のみによる VI と同じ流れとなることが予測 される.しかし， $F_{s w}$ が增大すると，定在波成分と進 行波成分を伴う場合の VI は，図 3 の進行波成分の みによる VI と比べ，大きさが大きくなり，さらに， 湾曲した流れを示すようになる.

ここで, 定在波成分と進行波成分を伴う場合の VI と進行波成分のみによる VI のベクトルの角度差と して定義される方向角度誤差 $\theta_{D A E}$ の分布を，図 6 に 示す.この図より， $F_{s w}$ が大きくなるほど，定在波成 分の有無による VI の流れの方向の違いが増大して いることがわかる。

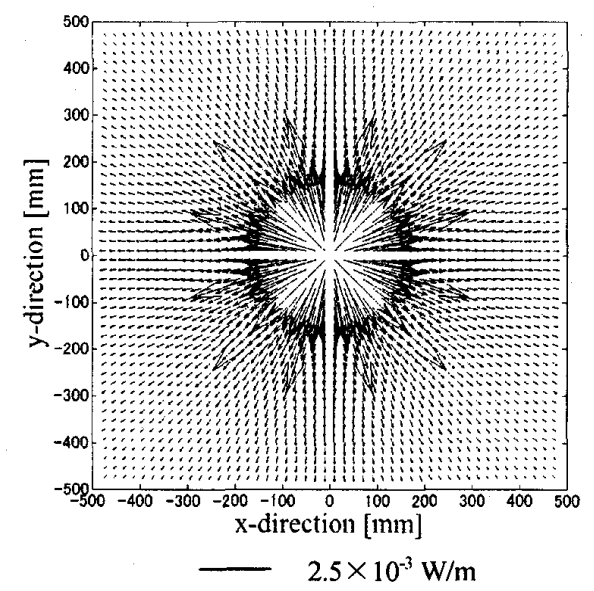

Fig. 3 VI distribution with traveling-wave component alone with the frequency of $69.739 \mathrm{~Hz}$

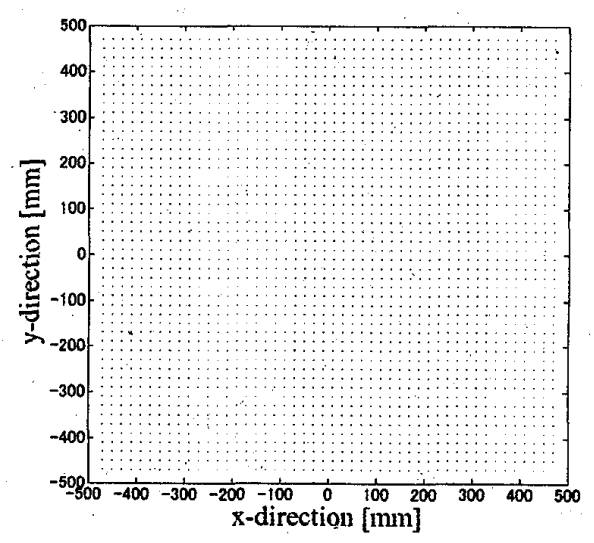

Fig. 4 VI distribution with standing-wave component alone with the frequency of $69.739 \mathrm{~Hz}\left(F_{s w}=1 \times 10^{-2} \mathrm{~N}\right)$ 


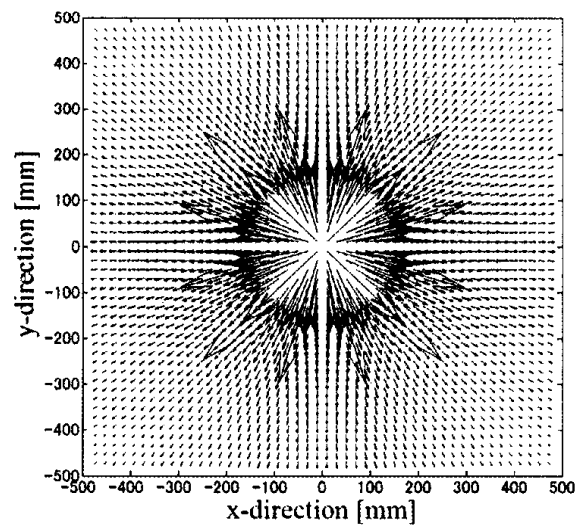

$2.5 \times 10^{-3} \mathrm{~W} / \mathrm{m}$

(a) $F_{s w}=1 \times 10^{-7} \mathrm{~N}$

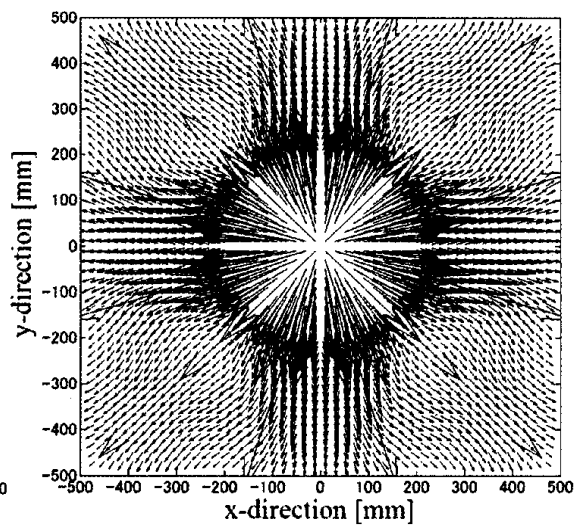

$2.5 \times 10^{-3} \mathrm{~W} / \mathrm{m}$

(b) $F_{s w}=1 \times 10^{-5} \mathrm{~N}$

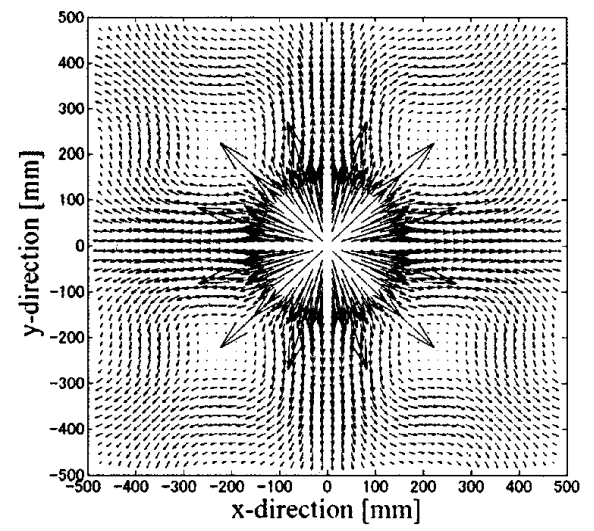

$2.5 \mathrm{~W} / \mathrm{m}$

(c) $F_{s w}=1 \times 10^{-2} \mathrm{~N}$

Fig. 5 VI distributions with both standing-wave and traveling-wave components

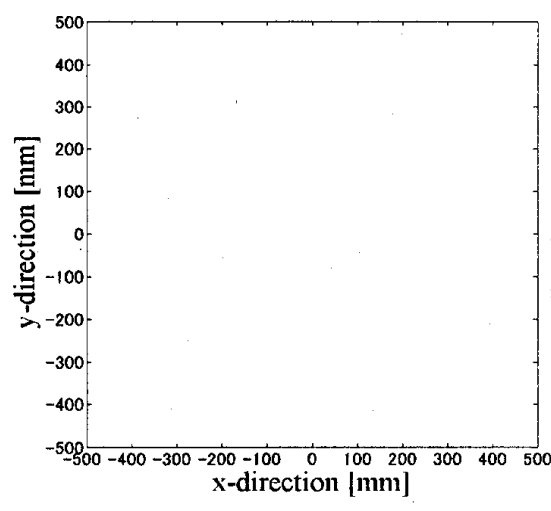

(a) $F_{s w}=1 \times 10^{-7} \mathrm{~N}$

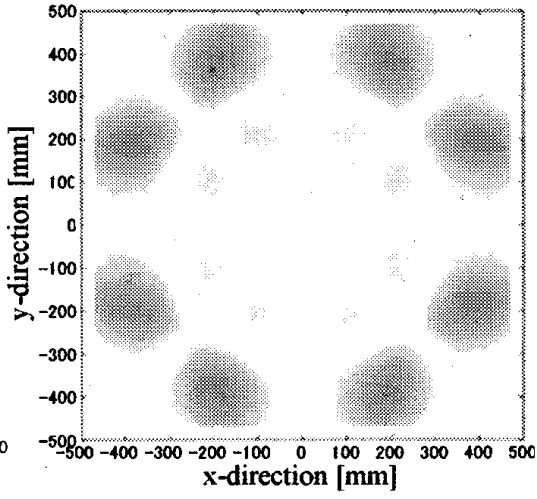

(b) $F_{s w}=1 \times 10^{-5} \mathrm{~N}$

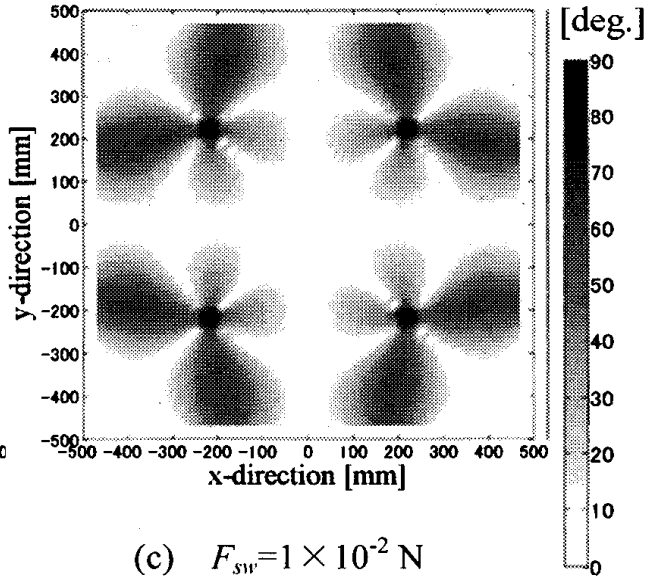

(c) $F_{s w}=1 \times 10^{-2} \mathrm{~N}$

Fig. 6 Distributions of direction angle error $\theta_{D A E}$ between

VI with both standing-wave and traveling-wave components and VI with traveling-wave component alone

$3 \cdot 2$ クロス項の影签 2 つの波動 $w_{a}$ および $w_{b}$ が同時に存在する振動場に VI を適用した場合，VI 算出式の第 1 . 項 $V I_{x, 1 s i}$ は次式のようになる.

$$
\begin{array}{r}
V I_{x, \mid s t}=B\left\{F\left[\frac{\partial^{3} w_{a}}{\partial x^{3}}\right] \cdot F^{*}\left[\frac{\partial w_{a}}{\partial t}\right]+F\left[\frac{\partial^{3} w_{b}}{\partial x^{3}}\right] \cdot F^{*}\left[\frac{\partial w_{b}}{\partial t}\right]\right. \\
\left.+F\left[\frac{\partial^{3} w_{a}}{\partial x^{3}}\right] \cdot F^{*}\left[\frac{\partial w_{b}}{\partial t}\right]+F\left[\frac{\partial^{3} w_{b}}{\partial x^{3}}\right] \cdot F^{*}\left[\frac{\partial w_{a}}{\partial t}\right]\right\}
\end{array}
$$

$2 つ$ 波動 $w_{a}$ および $w_{b}$ が同時に存在する場合には， 算出式中に, $w_{a}$ か $w_{b}$ の一方のみを含む式(2)の第 1 , 2 項のような非クロス項と, 1 つ項中に複数の波動 が存在する式(2)の第 3，4 項のようなクロス項が存 在する。これは，VI算出式の他の項についても同様 である。
各非クロス項は，各波動が単一で存在する場合で の VI によるエネルギー流れを表している，複数の 波動が存在する振動場を伝搬する振動エネルギーは, $1 つ 1 つ の$ 波動によって伝搬される振動エネルギー の総和であると考えられる.これより，非クロス項 の和が本来のエネルギ一流れを表していると考えら れる、しかし，実際に算出される VI には，エネル ギー流れの評価に介在しないクロス項が存在してい る.

図 7 9 $に F_{s w}=1 \times 10^{-7}, 1 \times 10^{-5}, 1 \times 10^{-2} \mathrm{~N}$ の条件 について，定在波成分と進行波成分を伴う場合の非 クロス項, クロス項およびそれらの和である全項に よるVI 分布を示す. 


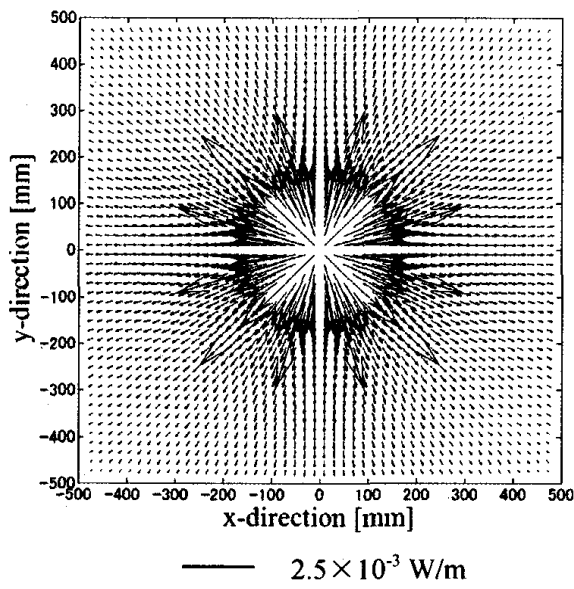

(a) Non-cross terms

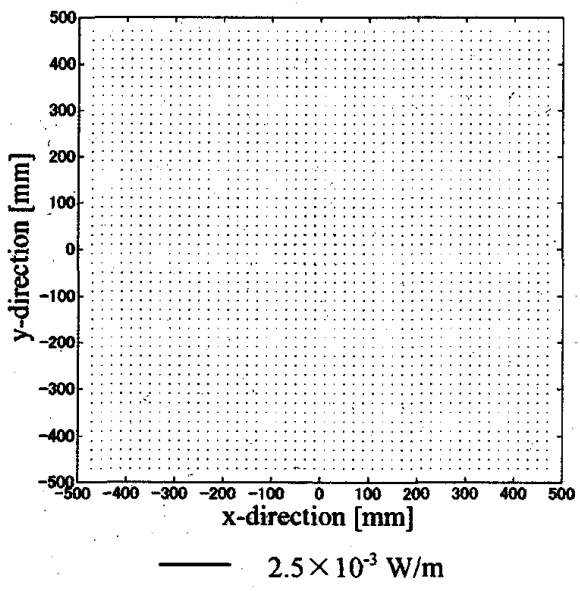

(b) Cross terms

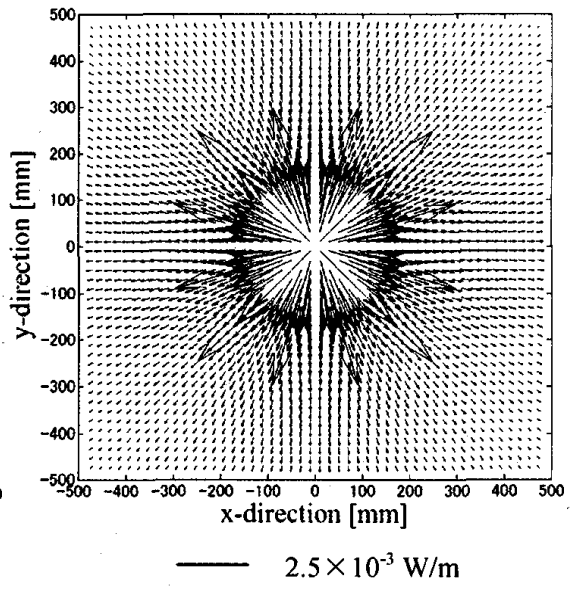

(c) All terms

Fig. 7 VI distributions by each terms with both standing-wave and traveling-wave components $\left(F_{s w}=1 \times 10^{-7} \mathrm{~N}\right)$

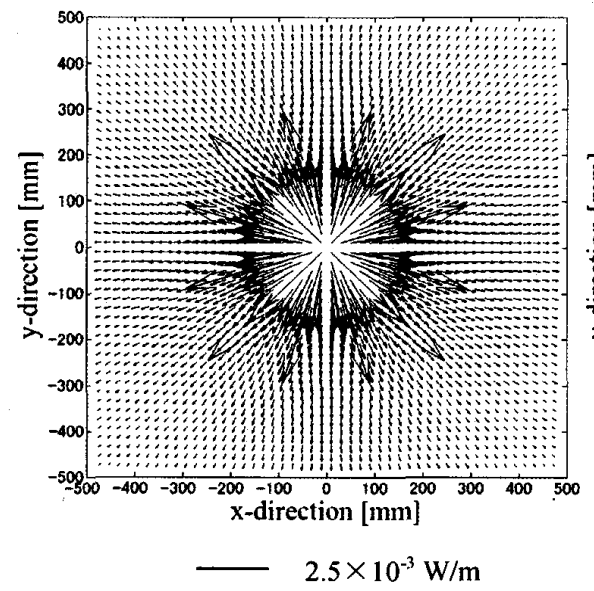

(a) Non-cross terms

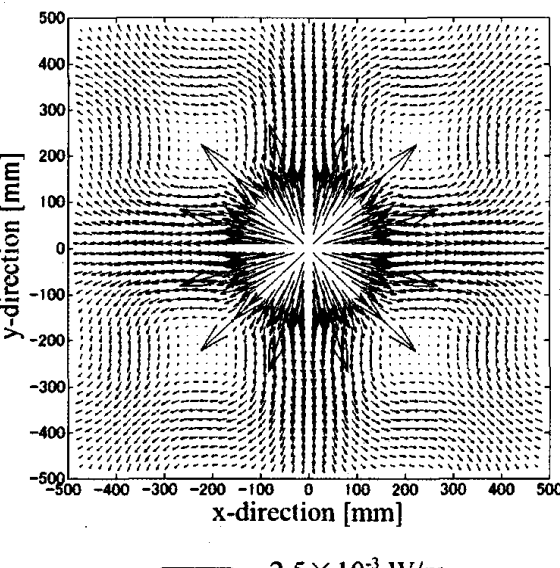

(b) Cross terms

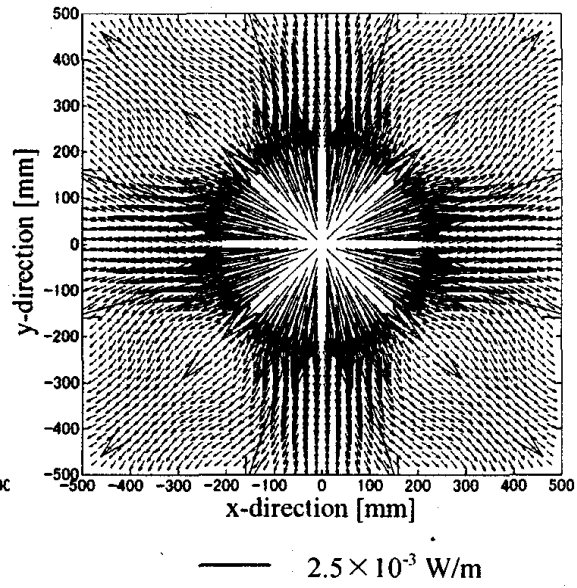

(c) All terms

Fig. 8 VI distributions by each terms with both standing-wave and traveling-wave components $\left(F_{s w}=1 \times 10^{-5} \mathrm{~N}\right)$

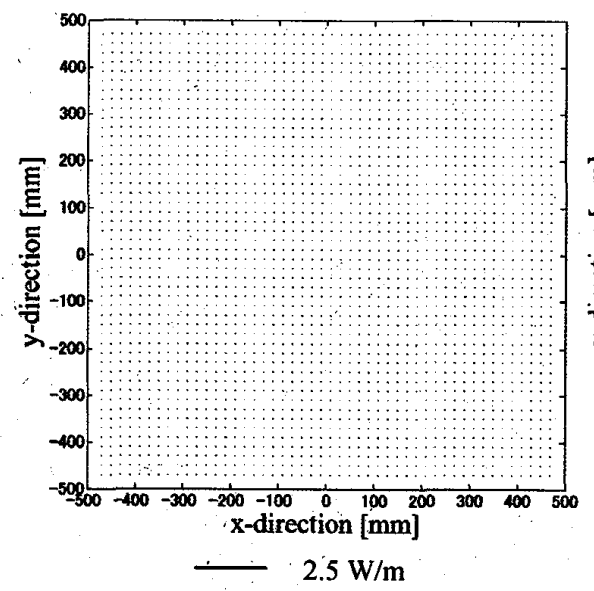

(a) Non-cross terms

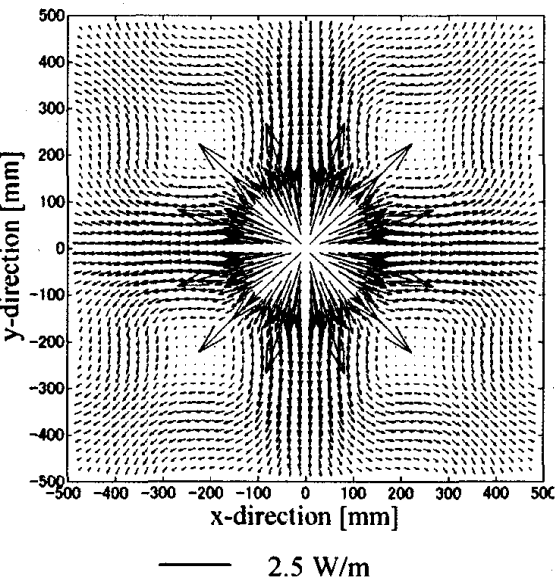

(b) Cross terms

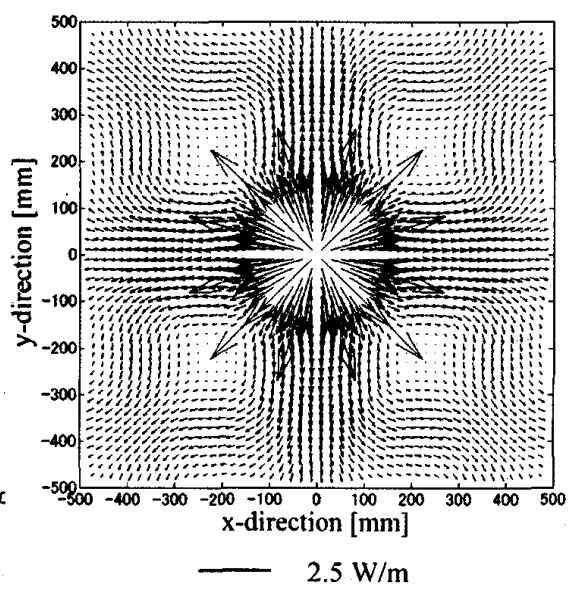

(c) All terms

Fig. 9 VI distributions by each terms with both standing-wave and traveling-wave components $\left(F_{s w}=1 \times 10^{-2} \mathrm{~N}\right)$ 
図 7〜9 のいずれにおいても, 定在波成分のみによ るVI は0であるので，非クロス項によるVI は図 3 の進行波成分のみによる VI と完全に同一の流れと なっており，ここからも非クロス項が本来のエネル ギー伝搬を表していることがわかる，また，図7に おいては，クロス項は 0 ではないが，非クロス項に 比べて無視できるほど小さく，全項によるVI は非 クロス項によるVI とほぼ等しい流れを示している. 図 8 においては，非クロス項とクロス項が同程度の 大きさを有しており，全項による VI が非クロス項 による VI から変化している，さらに，図 9 におい ては，非クロス項が無視できるほどクロス項が大き くなっており，クロス項が全項による VI の流れを 決定づける支配因子となっている。 なお，図 9 での ベクトルのスケールは図 7,8 と異なることに注意さ れたい.

$3 \cdot 3$ 進行波成分と定在波成分を伴う振動場にお けるVI の有用性 ここでは，進行波成分と定在 波成分が同時に存在する場合の VI の有用性につい て考察を行う。まず， $69.739 \mathrm{~Hz}$ において，進行波成 分の変位の振幅 $A_{t w}$ と定在波成分の変位の振幅 $A_{s w}$ の振幅比 $A_{n v} / A_{S w}$ を $\mathrm{VI}$ の有用性評価のためのパラメ ータとした。

図 10 に，振幅比 $A_{t w} / A_{s w}$ の変化に対する，全項に よるVI と非クロス項による VI の方向角度誤差 $\theta_{D A E}$ の推移を示す．なお，この $\theta_{D A E}$ は，定在波成分と進 行波成分を伴う平板において, 実際に算出される VI と本来のエネルギ一伝搬の方向の差異を表す.

ここで， $\theta_{D A E}$ の值と VI の有用性の関係について, 言及しておく．本来のエネルギー流れと VI ベクト ルの間に $\theta_{D A E}$ の角度誤差がある場合, 本来のエネル ギー流れ方向の VI ベクトルの成分は，VIベクトル の大きさを 1 とすると, $\cos \left(\theta_{D A E}\right)$ となる. 対して, 本来のエネルギー流れ方向と直角を成し，本来のエ ネルギー流れを表すことを阻害する成分は $\sin \left(\theta_{D A E}\right)$ となる.これら $\sin \left(\theta_{D A E}\right)$ と $\cos \left(\theta_{D A E}\right)$ の比 $\tan \left(\theta_{D A E}\right)$ が 1/2 以下，すなわち， $\theta_{D A E}$ が 26 度以下のときには， 本来のエネルギー流れを表す成分が主流であると考 えられる。これより, 本研究では, $\theta_{D A E}<26$ 度をVI の有用性の判断基準として用いる.

また, 図 11 に, 振幅比 $A_{t w} / A_{s w}$ の変化に対する, クロス項 $V I_{\text {cross }}$ と非クロス項 $V I_{\text {noncross }}$ の比 $V I_{\text {cross }} / V I_{\text {noncross }}$ の推移を示す。ここで, $V I_{\text {cross }}$ および $V I_{\text {noncross }}$ はVIベクトルの大きさを表す。なお, 図 10, 11 は, $F_{s w}$ を $1 \times 10^{-7} \sim 1 \times 10^{-2} \mathrm{~N}$ の範囲で変化させた
場合での解析領域内における全 VI 算出点での值を 示す.

図 10,11より, $A_{t w} / A_{s w}$ が小さくなり0に近づくほ ど，ほとんどの点で $\theta_{D A E}$ と $V I_{\text {cross }} / V I_{\text {noncross }}$ はともに増 加している. $A_{n v} / A_{s w}$ が 5 以上においては，ほとんど の点で $\theta_{D A E}$ が 26 度以下となっており, VI が本来の エネルギー伝搬を捉えていると考えられる．また， $A_{w} / A_{s w}$ が 5 以上においては, ほとんどの点で本来の エネルギー流れを表す非クロス項がクロス項より大 きくなっている。しかし， $A_{n w} / A_{s w}$ が 5 以下において は, $V I_{\text {cross }} / V I_{\text {noncross }}$ が 1 を超える点が増加し, VI の信 頼性を低下させている.

\section{4. 結言}

完全な定在波成分に進行波成分が別途付加された 振動場における VI に関する検討より, 以下の知見 が得られた。

（1）周波数の等しい複数の波動が同時に存在する場 合には，VI の算出式中に存在するが振動エネル ギー伝搬の評価に介在しないクロス項の影響が

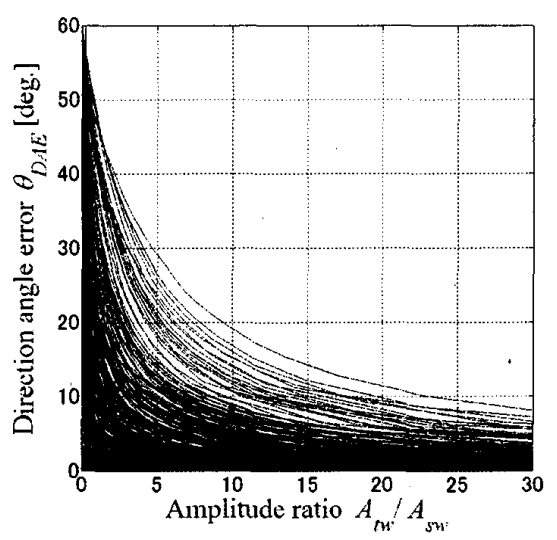

Fig. 10 Direction angle error $\theta_{D A E}$ between VI by all terms and VI by non-cross terms vs. amplitude ratio $A_{w w} / A_{s w}$

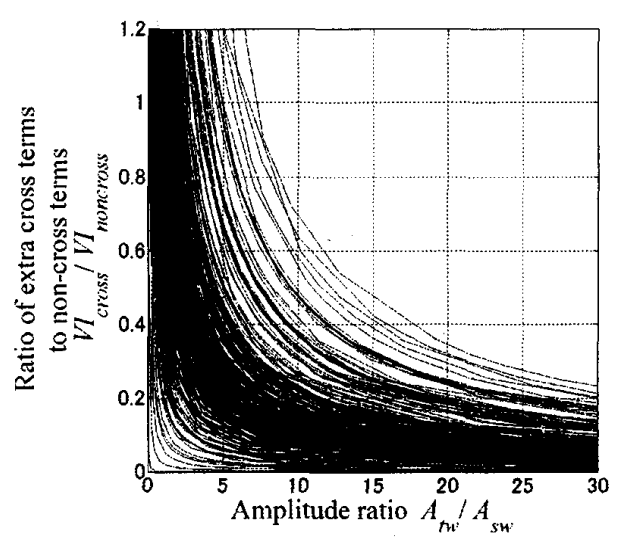

Fig. 11 Ratio of cross terms to non-cross terms $V I_{\text {cross }} / V I_{\text {noncrass }}$ vs. amplitude ratio $A_{w w} / A_{s w}$ 
顕在化し, VI と本来のエネルギ一流れの間に差 異が生じる場合があることがわかった。

（2）定在波成分は非伝搬成分であるため，振動エネ ルギーの伝搬成分を捉える VIに影響を与えない ことが予想されるが,クロス項を介して定在波成 分の有無によりVI が変化することがわかった。

(3) 進行波成分と定在波成分の変位の振幅比が 5 以 上の場合には，クロス項と比較して，非クロス項 が大きく，本来のエネルギ一流れをVIにより捉 えることができることを示した。

(4) VIにおける湾曲したエネルギー流れの形成要因 の1つとして,クロス項の影響が挙げられること がわかった。
(1) Noiseux, D. U., Journal of Aciustical Society of America, 47-1, (1970), pp. 238-247.

(2) Pavic, G., Journal of Sound and Vibration, 49-2, (1976), pp. 221-230.

(3) Kojima, N., et al., Trans. Jpn. Soc. Mech. Eng., Vol. 57, No. 533, C (1991), pp. 130-134. (in Japanese)

(4) Ebita, Y., et al., Proceeding Jpn. Soc. Mech. Eng., Vol. 2003, No. 41, C (2003), pp. 325-326. (in Japanese)

(5) Kojima, N., et al., SAE 1997 Transactions (Journal of English), SAE Paper 972035, (1997), pp. 1289-1295.

(6) Kojima, N., et al., Trans. Jpn. Soc. Mech. Eng., Vol. 55, No. 518, C (1989), pp. 2519-2526. (in Japanese)

(7) Tanaka, N., et al., Trans. Jpn. Soc. Mech. Eng., Vol. 59, No. 566, C (1993), pp. 3086-3094. (in Japanese)

(8) Tanaka, N., et al., Jpn. Soc. Mech. Eng. international Journal, vol. 37, No. 3, C (1994), pp. 588-594.

(9) Yahara, M., et al., Proceedings of $14^{\text {th }}$ International Congress on Sound and Vibration, (2007), No.413

(10) Honda, S., et al., Trans. Jpn. Soc. Mech. Eng., Vol. 60 , No. 574, C (1994), pp. 1933-1940. (in Japanese) 